\title{
油脂の酸化測定のための TBA 法における
}

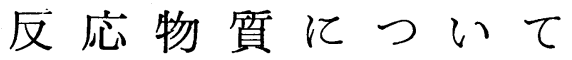

\author{
浅川具 美*・野村幸弘**・松下雪 郎 \\ 京都大学食糧科学研究所 (宇治市五ヶ庄) \\ * 同志社女子大学家政学部 (京都市上京区今出川通寺町西入) \\ ** 八ウス食品工業株式会社（東大阪市御橱）
}

On the Reacting Compounds in the TBA Method for the Determination of Lipid Oxidation

\author{
Tomomi Asakawa*, Yukihiro Nomura** and Setsurō Matsushita \\ Research Institute for Food Science, Kyoto University (Uji) \\ Present address * Doshisha Women's College (Kyoto) \\ ** House Food Industry Co., (Higashiosaka)
}

When TBA method is applied to oxidized lipids, red color (about $530 \mathrm{~nm}$ ) and yellow color (about $450 \mathrm{~nm}$ ) are produced. The red color is rather stable and is used for the analysis, but the yellow color is unstable. An attempt was made to solve the mechanism of producing the yellow color by comparing the results of Sidwell's method (mainly red color) and Ottlenghi's method ( 2 colors). The reaction of hydroperoxides with TBA and the reaction under addition of $\mathrm{Na}_{2} \mathrm{SO}_{3}$ were also tested. From these experiments, the compound developing yellow color was deduced to be caused by an aldehyde which came from a primary decomposed product of hydroperoxides by further oxidative decomposition.

\section{1 緒 言}

油脂の酸化変質の程度の測定法として，TBA 法は広 く利用されている。しかしながら，この方法には種々の 問題点が残されており, 過酸化物価, カルボニル価, 酸 価などに併せて，補助的な值として利用されているにす

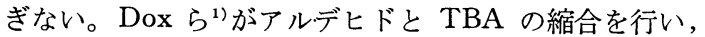
Bernheim $ら^{2)}$ が食品の酸化変敗の測定に適用して以来, この方法は食品研究者の注目を集め, 幾多の研究がなさ れてきた。それらについては大薮ら ${ }^{3)}$ の総説に詳しい。 それらの種々の論義をみるに, この方法は簡便に使用で きる一方, $\mathrm{pH}$, 加熱温度, 加熱時間, かきまぜの条件, 光線, 呈色物の放置時間などの影響を受けやすく, 再現 性に乏しいものとなっている。そこで，これを改良す るため, TBA 法にはいくつかの変法が考案されてき た (4) 9)。しかしながら，いずれも不満な点があって根本 的な解決には至っていない。それは発色の原理における 解明が不充分なためと考えられる。

TBA は油脂の酸化生成物中のマロンアルデヒドと反 応すると考えられ ${ }^{10)}$, Sinnhuber ${ }^{11)}$ は TBA との呈色 物質は 2 分子の TBA と 1 分子のマロンアルデヒドが縮
合したものと推定した。TBA はマロンアルデヒドの外 に，種々のアルデヒドと反応することも報告され，ジエ ナール ${ }^{7)}$ ，グリオキザール ${ }^{12)}$ などと反応して $540 \mathrm{~nm}$ 付 近に最大吸収を示寸赤色反応物が生成し，飽和アルデヒ ド7),13)，モノエナール ${ }^{7) ， ク ゙ リ セ リ ン ア ル テ ゙ ヒ ト ゙(4) な と ゙ ~}$ は $450 \mathrm{~nm}$ 付近に吸収を持つ黄色の化合物を生ずると報 告されている。また種々のオレンジ色素を生ずる化合物 も明らかにされている(5)。なお Tarladgis $ら^{5)}$ と Yu ら ${ }^{16)}$ はヒドロペルオキシドが測定に影響すると述べた。

さて, この方法を油脂の酸化測定に応用する際に, 実 際に呈色に関与する化合物は，上記の化合物中にあると 考えてよいのだろらか。マロンアルデヒドが典型的な呈 色物質として採り上げられているが，油脂の酸化におい てマロンアルデヒドは検出し難いものであり，まだ疑問 をはさむ余地はあるだろう。

本報においては，TBA 法として酢酸酸性溶液で抽出 後加熱する Sidwell の方法(4) と, 酸化油をトリクロロ酢 酸存在下 TBA と加熱後クロロホルムで油脂分を除く Ottolenghi の方法 ${ }^{6}$ を使用し，その相異点を明らかにし た。またリノール酸メチルのヒドロペルオキシドをTBA と反応させると，はじめは呈色しないが，反応液を放置 
すると黄色色素を生ずること，あるいは亜硫酸ナトリウ ム存在下に㧍ける TBA 反応の結果, 黄色色素の生成し ないことなどから, 油脂酸化生成物中の TBA と反応す る化合物についての論義を行うものである。

\section{2 実験と結果}

\section{$2 \cdot 1$ 材 料}

脂肪酸と大豆油は市販品を用いた。サフラワー油は吉 原製油株式会社より提供された。リノール酸メチルヒド ロペルオキシド (MLHPO) はカラムクロマトグラフィ 一と薄層クロマトグラフィーにより精製した ${ }^{17) 。}$

\section{$2 \cdot 2$ 測定方法}

$2 \cdot 2 \cdot 1$ TBA 法としては, 主として Ottolenghi (O-

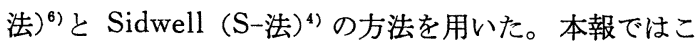
の両方法の比較が論点となるので, それらの方法につい て略記する。

O-法 試料 $0.1 \mathrm{~m} l に 35 \%$ トリクロロ酢酸 (TCA) $1 \mathrm{~m} l, 0.335 \% \mathrm{TBA}$ 試薬 $2 \mathrm{~m} l$ を加え, 沸騰浴中で 15 $\min$ 加熱し, 冷却後 $1 \mathrm{~m} l$ の水酶酸と $2 \mathrm{~m} l$ のクロロホ ルムを加え, 振とう後遠沈する。上澄み液を用いて吸光 度を測定する。試料 $1 \mathrm{~g}$ 当たりの O.D. として標示し た。

S-法 試料 $0.5 \mathrm{~m} l$ にクロロホルム $10 \mathrm{~m} l, 0.335 \%$ TBA 試薬 $10 \mathrm{~m} l$ を加え, $4 \mathrm{~min}$ 振と万後遠沈して, 上澄み液を沸騰浴中で $30 \mathrm{~min}$ 加熱し, 冷却後, 吸光度 を測定する。

\section{$2 \cdot 2 \cdot 2$ GC-MS 分析}

島津-LKB 9000 を用いた。担体にクロモソルブー W, $60 \sim 80$ mesh, 液相を $3 \%$ SE-52 としてガラスカラム $(0.3 \times 200 \mathrm{~cm})$ につめ, $100^{\circ} \sim 250^{\circ} \mathrm{C}$, 昇温 $\left(5^{\circ} \mathrm{C} / \mathrm{min}\right)$ 法により，ヘリウムガス $(30 \mathrm{~m} l / \mathrm{min})$ で展開した。

運転条件は次のようである。イオンソース温度 $330^{\circ}$, セパレーター温度 $290^{\circ} \mathrm{C}$, イオン化電圧 $70 \mathrm{eV}$, トラッ プカレント $60 \mu \mathrm{A}$, アクセレレーター電圧 $3.5 \mathrm{kV}$.

P.O.V. はヨウ素滴定法 ${ }^{18}$ により, $\mathrm{meq} / \mathrm{kg}$ で標示し た。

\section{$2 \cdot 3$ 脂肪酸酸化の時間的経過}

$5 \mathrm{~m} l$ のリノール酸メチルならびにリノレン酸を $50 \mathrm{~m} l$ の三角フラスコに入れ， $37^{\circ} \mathrm{C}$ の空気浴中に置いて，酸 化の進行過程を P.O.V, TBA 法 (O-法) で追跡した (Fig.-1, 2)。MLHPO はロータリーエバポレーターのフ ラスコ中に入れ，回転させながら $37^{\circ} \mathrm{C}$ に置いた（Fig.3)。リノール酸.ィチルとリノレン酸においては, P.O.V. のピーク（それぞれ 12 日，6 日）に少し後れて TBA $532 \mathrm{~nm}$ (赤色色素) の O.D. のピーク（それぞれ 15 日， 8 日）が現れた。ただし，リノレン酸の場合赤色色素の 出現はリノール酸メチルに比べ早かった。TBA $450 \mathrm{~nm}$ の色素 (黄色色素) はリノール酸メチルの場合には赤色
色素の増減につれて変動したが，リノレン酸においては ほとんど生じなかった。MLHPO の場合は P.O.V.の 減少につれ, 赤色色素, 黄色色素共に増大しはじめ, そ の O.D. は後者の方が大であった。なお，Fig.-3 の実

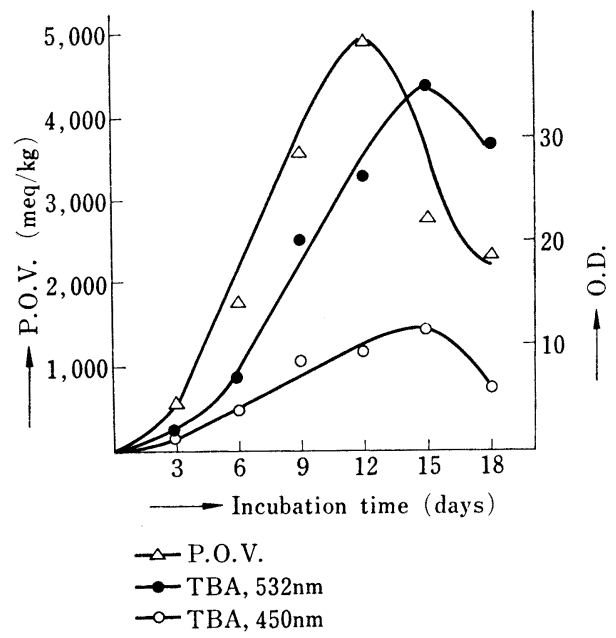

Fig.-1 Autoxidation process of methyl linoleate. Incubated at $37^{\circ} \mathrm{C}$.

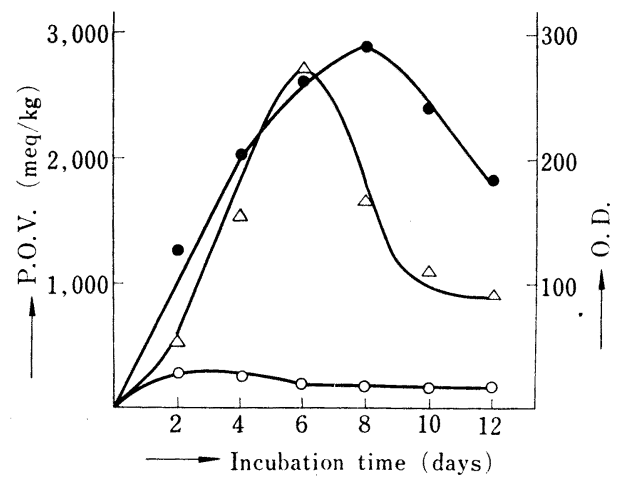

Fig.-2 Autoxidation process of linolenic acid. Incubated at $37^{\circ} \mathrm{C}$. Symboles are the same as in Fig.-1.

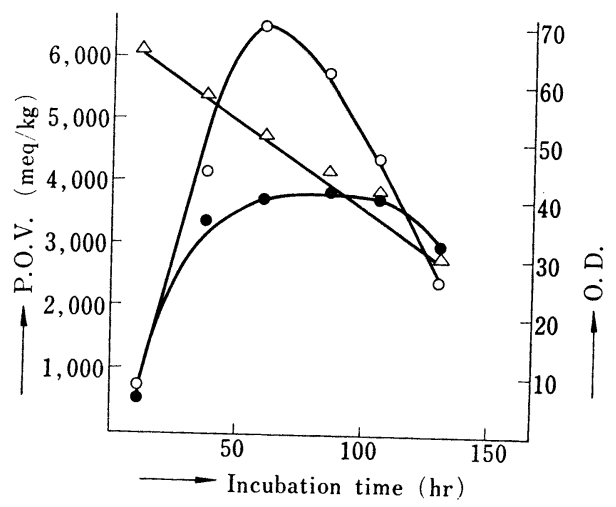

Fig.-3 Decomposition process of MLHPO. Incubated at $37^{\circ} \mathrm{C}$. Symboles are the same as in Fig. -1 . 
験においては, 約 $100 \mathrm{hr}$ のインキューベーションで MLHPO は薄層クロマトグラフィー17)では認められな いまでに消失していた。その後に存在する P.O.V.は二 次生成物中に生じたヒドロペルオキシドによると考えら れる。

\section{$2 \cdot 4$ 油脂の酸化の時間的経過}

それぞれ $20 \mathrm{~m} l$ のサフラワー油と大豆油を $100 \mathrm{ml}$ の 三角フラスコに入れ， $50^{\circ} \mathrm{C}$ の空気浴中にインキュベー トした (Fig.-4, 5)。その間 1 日 1 回は振り混ぜた。共に 2 週間目ころより P.O.V. が上昇し始めたが, 赤色色素 の増大は大豆油の方が早く, そのピークの生ずる日 (28 日）は P.O.V.のピークとほぼ一致した。サフラワー油 の場合は P.O.V.のピーク (23 日) に後れて赤色色素 のピーク (28 日) が現れた。黄色色素についてはさほど の相異はみられなかった。これらの油には, 天然抗酸化 凨も含まれているので, 酸化の速さには違いがあって当 然であるが, サフラワー油は不飽和脂肪酸としては主と してリノール酸を含むものであり, 大豆油はリノール酸 に加えリノレン酸をも含む特徴がある。Fig.-1 と Fig.-

4, Fig.-2 と Fig.-5 の図型がよく似ているのは含まれ る不飽和脂肪酸が類似するためである。

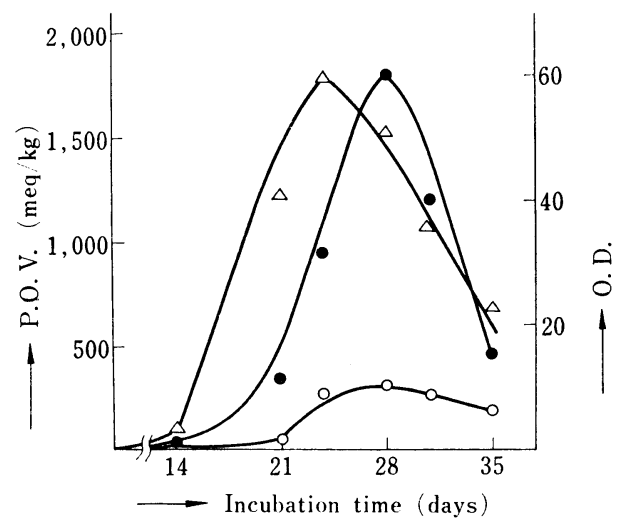

Fig.-4 Autoxidation process of safflower oil. Incubated at $50^{\circ} \mathrm{C}$. Symboles are the same as in Fig. -1 .

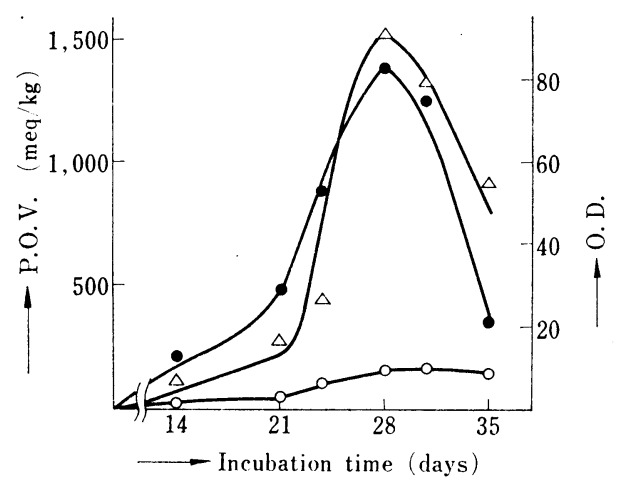

Fig.-5 Autoxidation process of soybean oil. Incubated at $50^{\circ} \mathrm{C}$. Symboles are the same as in Fig.-1.

\section{5 黄色色素の生成}

酸化したリノール 酸メチルを用い O法により発色後, 室 温に放置して，その スペクトルの変化を 測定した (Fig.-6)。 その結果赤色色素は 変化しないが, 黄色 色素は増大した。さ らに時間が経つと黄 色色素も減少した。 これは, 加熱して反 応させたあと, 何ら かの化合物から変化 してアルデヒドとな り, 残存した TBA と反応したものと考 えられる。なお黄色 色素の生成は, 油脂 の種類, いいかえれ

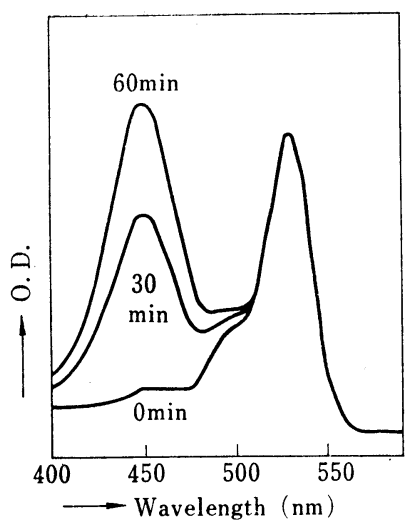

Fig.-6 Absorption spectrum of TBA-reacted oxidized methyl linoleate followed by O-method.

The colored solution was left at room temperature and the spect rum was measured after 30 and $60 \mathrm{~min}$.
ば含まれる不飽和脂肪酸の 種類により 異なるようであ る。リノール酸ならびにリノレン酸を含む大豆油におい ては比較的黄色色素の生成は少なく, リノール酸メチ ル，あるいは主にリノール酸を含むサフラワー油におい ては生成量が比較的多かった。

\section{$2 \cdot 6$ 黄色色素の除去}

黄色色素は, 赤色色素の生成, 発色を阻害するもので はないが, 黄色色素の不安定さと色素生成物質の不明り ょうさは TBA 法に対する信頼度を弱めることとなって いる。いま S-法に従うと, 主として赤色色素生成物が抽 出され発色する (Fig.-7 と全く同じ赤色色素型のスペ クトルを示す)。この方法を詳細に検討すると, 赤色色 素を生ずるものは，もともと酶酸酸性において抽出され るもの，あるいは TBA と複合体を形成した上酶酸酸性 で抽出されるものといらことがわかる。したがって， O-法と対比するとき, 黄色色素を生成する化合物は, 酢 酸溶液に不溶性の物質であったものが, TBA と加熱に 際して分解なり変形して水溶液に移行することになり, しかもクロロホルムでは抽出不可能といら性質を持つよ らになったものと考えられる。分子量的には酶酸溶液抽 出可能である低分子 (S-法で酢酸溶液に抽出されること から）の赤色色素発生物質と, クロロホルム可溶の長鎖 化合物 (S-法では黄色色素生成物質の前駆体はクロロホ ルム層に含まれていることから）との中間に位するもの であろう。S-法によらずに黄色色素を除くにはそのよう な中間体を生じさせないようにしなければならない。

\section{$2 \cdot 7 \mathrm{Na}_{2} \mathrm{SO}_{3}$ 存在下の $\mathrm{TBA}$ 反応}




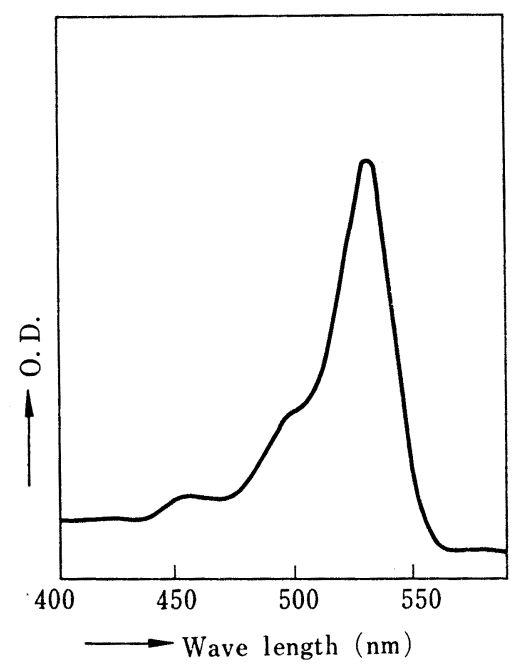

Fig.-7 Absorption spectrum of TBA-reacted oxidized methyl linoleate followed by O-method when $\mathrm{Na}_{2} \mathrm{SO}_{3}$ is co-exist.

上述のように O-法によると, 反応液は時間の経過と 共に黄色色素を生ずる。これは放置中に反応が緩やかに 進行することを意味し，それが酸化反応に基づく可能性 がまず考えられる。そこで，TBA と加熱後反応液中の 溶存酸素を除去するため $\mathrm{Na}_{2} \mathrm{SO}_{3}$ 溶液を加えたとこ $ろ^{19)}$, 黄色色素の増加はストップした (Fig.-7)。そこ で, 発色加熱に先立って, $0.1 \% \mathrm{Na}_{2} \mathrm{SO}_{3}$ (無水) を含む TBA 溶液 (新鮮溶液) を用いると, 反応後の黄色色素 の発生は完全に止まると共に, 赤色色素の生成が増加し た。 $\mathrm{Na}_{2} \mathrm{SO}_{3}$ 無添加の標準法に比べ 1.3 1.7 倍の増加 を示した。なお赤色色素は $1 \mathrm{hr}$ 後も変化がなかった。 ただし, $\mathrm{Na}_{2} \mathrm{SO}_{3}$ の効果は酸素除去に限られるわけでは ない。

\subsection{MLHPO 亡 TBA との反応}

MLHPO と TBA を O-法により反応させても全く 呈色しなかった。しかし, 反応終了液を室温に放置する と黄色色素 (吸収極大 $450 \mathrm{~nm}$, 図は略す) が生じてき た。これは MLHPO の加熱分解により生じたものは TBA と反応しないが，それが徐々に変化してアルデヒ ドとなることを意味するのであろう。 $\mathrm{Na}_{2} \mathrm{SO}_{3}$ の存在下 で発色させたものは，もちろん放置後も色素を生じな かった。

\section{9 リノール酸メチル酸化生成物の GC-MS 分析}

リノール酸メチルを酸化させたものを（P.O.V. 約 $2,300)$, 薄層クロマトグラフィーにかけ（調製用プレー ト $0.25 \mathrm{~mm}$, エチルエーテル : $n$ 一ヘキサン: 酢酸, 8 : $7: 0.1)$, 二次生成物 $\left(R_{f} 0 \sim 0.3\right)$ をエーテルで抽出, GC-MS にかける一方 (Fig.-8), エーテル抽出物はエ ーテルを追い出してへキサン溶液としたのち, $25 \%$ 酢酸 で洗い（S-法抽出残分に当たる）へキサン層を分析に供

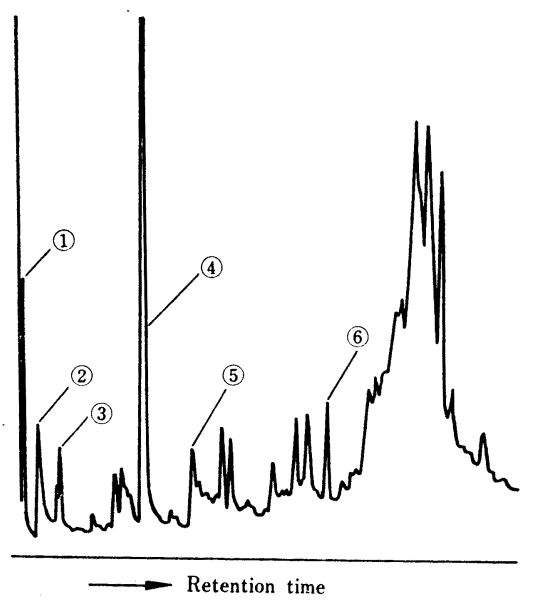

Fig.-8 Gas chromatogram of secondary products from oxidized linoleate. (1) hexanal ${ }^{17)}$, (2) nonadienal, (3) methyl octanoate ${ }^{17)}$, (4) 8formylmethyl octanoate ${ }^{17)}$, (5) 8-formoxy methylnonanoate ${ }^{10)}$, (6) methyl linoleate.

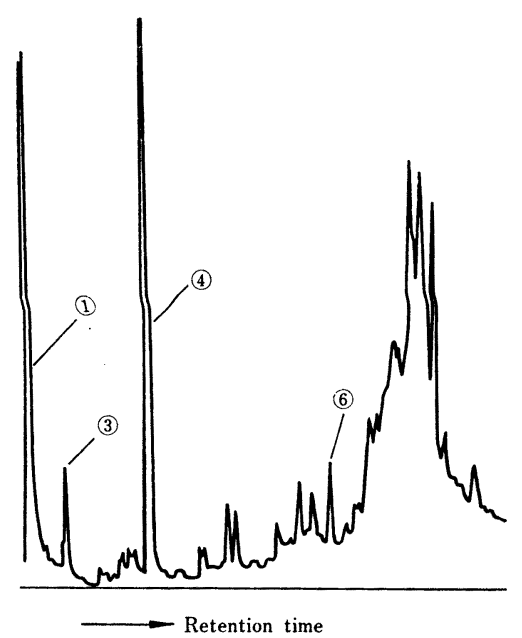

Fig.-9 Gas chromatogram of acetic acid-washed secondary products from oxidized linoleate. The numbers are the same as in Fig.-8.

した(Fig.-9)。主なピークについては質量スペクトルに より同定した。両図を比較すると，中間に生ずるへキサ ナール,オクタン酸メチル, 8-ホルミルオクタン酸メチ ルは変化なく, 酢酸では除かれないことがわかる。酢酸 で抽出されたものとしては，ノナジェナールと 8-ホル ムオキシノナル酸メチルが顕著であるが, 前者は赤色物 質を形成する可能性は濃く" ${ }^{7}$, 後者はアルデヒドではな いので発色しないであろう。

\section{3 考察}

油脂の酸化過程に TBA 法を適用するとき, $532 \mathrm{~nm}$ 付近に吸収をもつ赤色色素と $450 \mathrm{~nm}$ 付近に吸収をもつ 黄色色素を生ずることはよく知られた事実である。この 
うち, 赤色色素は安定であるから, 分析法としては一応 利用できる。黄色色素は不安定で, 利用はできないが, 一体黄色色素を生ずるものは何だろうか。TBA 法の信 頼性を高めるためにも発色の機構を探るのは意義のある ことであろう。

緒言にも述べたように, 赤色色素はマロンアルデヒ ド(1)やジエナール に基因するものであり，黄色色素は 飽和アルデヒド7),13),14)やモノエナール7によるといわれ る。なお黄色色素の不安定さについてもすでに述べられ ている ${ }^{5,9) 。 ~}$

上述の実験結果から，赤色色素生成物としてノナジェ ナールマの可能性は非常に高いと考えられるが，本報に おける興味はむしろ黄色色素生成についてである。黄色 色素を生ずる化合物については, 実験結果よりその輪郭 を画くことが可能となった。すなわち，この化合物はク ロロホルムには溶けるが酢酸溶液で抽出されなかった物 質が, TBA との加熱に際し, 分解あるいは変形してク ロロホルムよりはむしろ酢酸溶液へ溶けるようになり， それがさらに緩やかな反応によって過剩に存在する TBA と反応して黄色色素を生じたものと考えられる。 発色の本体である分子の大きさは抢そらく赤色色素を生 ずるというマロンアルデヒドよりも分子の大きなアルデ ヒドであろう (2.6 参照)。リノール酸の場合はヒド ロペルオキシドの分解に際しそのような中間体が生ずる 可能性は多く（二重結合が 2 つで最初の生成物はモノヒ ドロペルオキシドであり, 分解に際して中間で切れる可 能性が高い ${ }^{17)}$, リノレン酸においては分解が急激で

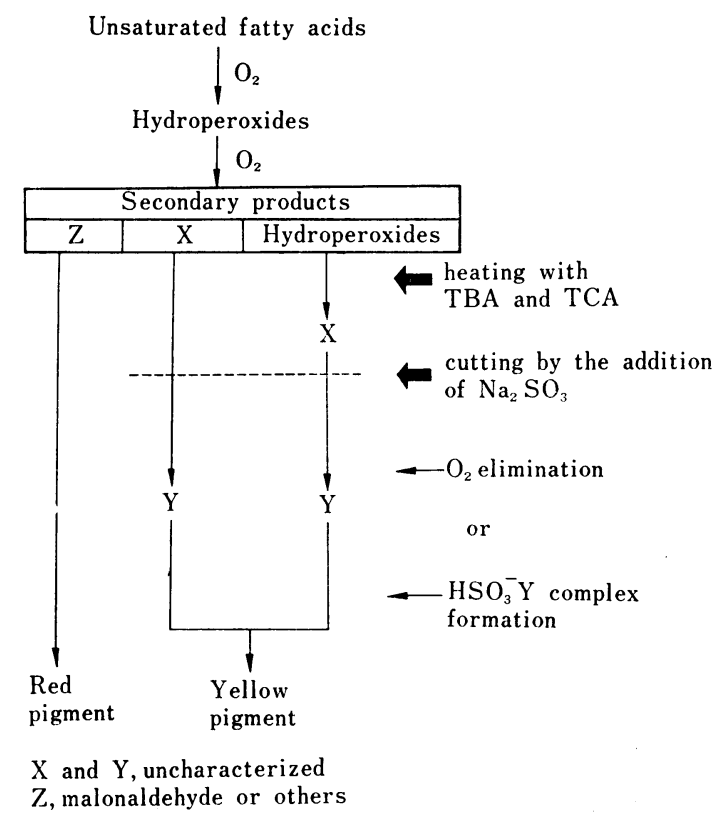

Fig.-10 Possible mechanism of the development of color in TBA method.
(二重結合が 3 つのため分解物が更に酸化分解を受けや すい), 一気に低分子のものとなり，中間体が得られ難 いと想像される。実際, リノール酸メチルとサフラワー 油の酸化に際して黄色色素の出現が顕著であり,リノレ ン酸, 大豆油の酸化に際してその量の少ないことからも 示唆されるところである。さらに黄色色素が MLHPO から生ずることからも Fig.-10 のような図式が描かれ る。

なお, 酸化油脂と TBA との加熱に際し, 新たな油脂 の酸化が進行し, 過大な值を与えるとして, 抗酸化剂, BHA を添加する方法 ${ }^{8}$ が提案されているが，上記実験 結果は, それとは反対に, 加熱中に呈色物質が減少する ことを意味しており, $\mathrm{Na}_{2} \mathrm{SO}_{3}$ 添加下での反応において は，呈色度がかえって増大した $(532 \mathrm{~nm})$ のである。こ れは呈色物質であるアルデヒド（一応マロンアルデヒド としておく）が加熱中に一部酸化して減少するためと考 え得るであろう。なお, ここでの $\mathrm{Na}_{2} \mathrm{SO}_{3}$ 添加の効果 は, この塩が有機化合物に対して直接還元的に作用しう るほど強力ではないことから，呈色分子に直接衝いたと は考え難い。そこで一つにはこの塩の酸素除去効果 ${ }^{19)}$ 考えられるが,一つには酸性下 $\mathrm{HSO}_{3}$ - のアルデヒドと の選択的（マロンアルデヒドは妨害されない）コンプレ ックス形成 ${ }^{20)}$ も無視しえないであろう。

Fig.-10 に提案した X, Y の構造は未同定であるが, ヒドロペルオキシドよりの二次生成物中の $\mathrm{X}$ は TBA 反応後直ちには呈色せず, 時間の経過とともに黄色色素 を生ずることから，いったん加熱操作により Y となっ たのち室温中で徐々に TBA と反応して黄色色素を生ず る。分画精製したヒドロペルオキシドと TBA とを加熱 すると無色であるが, X が生じており, 更に放置するこ とにより (Y を経て) 呈色する。 $\mathrm{X}, \mathrm{Y}$ の本体について は今後の課題として残される。

なお，ここに提案したものは，精製した脂肪酸または トリグリセリドを用いた場合にのみいえることであっ て, 食品中の脂質に適用する場合には, 糖類なども存在 するので, さらに別の要因も考慮する必要がある。

ガスクロマトグラフィーについては食糧科学研究所技官 泉谷 定男氏の労をわずらわした。ここ㴬意を表する。

(昭和 49 年 7 月 31 日受理)

\section{文献}

1) A.W. Dox, G.P. Plaisance, J. Amer. Chem. Soc., 38, 2156, 2164 (1916)

2) F. Bernheim, M.L.C. Bernheim, K.M. Wilbur, $J$. Biol. Chem., 174, 257 (1948)

3) 大薮, 太田, 油化学, 18, 699 (1969)

4) C.G. Sidwell, H. Salwin, M. Benca, J.H. Mitchell Jr., J. Amer. Oil Chem. Soc., 31, 603 (1954)

5) B.G. Tarladgis, B.M. Watts, J. Amer. Oil Chem. Soc., 37, 44 (1960)

6) A. Ottolgenghi, Arch. Biochem. Biophys., 79, 355 
(1959)

7) G.A. Jacobson, F.A Kirkpartick, H.E. Goff, Jr., $J$. Amer. Oil Chem. Soc., 41, 124 (1964)

8) T.C. Yu, R.O. Sinnhuber, J. Amer. Oil Chem. Soc., 44, 256 (1967)

9) A.J. de Koning, M.H. Silk, J. Amer. Oil Chem. Soc., 40, 165 (1963)

10) S. Patton, G.W. Kurtz, J. Dairy Sci., 34, 669(1951)

11) R.O. Sinnhuber, T.C. Yo, T.C. Yu, Food Res., 23, 626 (1958)

12) N.L. Smith, I.J. Tinsley, E.C. Bubl, Food Technol., 14, 317 (1960)
13）天野, 食衛誌, 7, 334 (1966)

14) S. Patton, Food Res., 25, 554 (1960)

15) F. Feigel, E. Libergott, Anal. Chem., 36, 132(1964)

16) T.C. Yu, R.O. Sinnhuber, J. Amer. Oil Chem. Soc., 41, 540 (1964)

17) J. Terao, T. Ogawa, S. Matsushita, Agr. Biol. Chem., 印刷中

18) B.D. Sully, Analyst, London, 79, 86 (1954)

19）“分析化学辞典” p. 51 (1971), 共立出版

20）川城, 藤井, 岩尾編, “新版食品添加物”, p. 70 (1973), 恒星社厚生閣 